\title{
O HUMANISMO DE TOMMASO FIORE
}

Norberto Bobbio'

No presente trabalho busca-se ponderar as alternativas político-jurídicas, a partir do término da vigência do Tratado da Antártida (2041) e da moratória de exploraçáo mineral no continente branco (2048), estabelecida pelo Protocolo de Madri. Assim, faz-se um estudo das atuais normas vigentes que regulamentam o continente antártico e estuda-se qual a melhor alternativa para o futuro deste. Observa-se a farta demanda da sociedade em relaçâo às fontes de energia dos combustíveis fósseis e seus derivados, analisando as consequências trazidas pela superexploraçăo dos recursos e os impactos ambientais causados pelo proveito desregrado dos mesmos, uma constante no continente Ártico, polo que náo é protegido por um tratado efetivo de preservaçăo ambiental, tampouco pela moratória da exploraçăo mineral do Protocolo de Madri.

O meu conhecimento ideal de Tommaso Fiore remonta aos tempos, já longínquos, do "grupo" de Augusto Monti. O conhecimento real veio muitos anos depois; mas este, ao invés de se sobrepor àquele e cancelá-lo, como frequentemente acontece, por assim dizer, fundiu-se a aquele, entrou nele como na sua moldura natural, de modo que năo é mais possível distingui-los, e para ver e entender o quadro inteiro săo necessários todos os dois.

Monti deve ter aprendido com seu pai - o "papai" de Sansôssi - a arte de reinventar as histórias verdadeiras, de criar uma epopeia familiar a partir de pequenos fatos cotidianos, e de povoá-las de personagens fabulosos. O "grupo" năo teria existido nem teria podido durar tanto se Monti náo o tivesse mantido unido recriando para este a história do recentíssimo ontem, engolido por trás de nós por um abismo, como se tivesse acontecido um terremoto, como uma história exemplar, tecida por fatos memoráveis, animada e enobrecida, ela também, por personagens extraordinários. Um destes personagens foi justamente Tommaso Fiore. O qual nos foi apresentado, lembro bem, por ocasiăo da apariçăo da Poesia di Virgilio [Poesia de Virgilio], portanto, em torno de 1930, quando o grupo se transferiu do café frequentado por subalternos da rua Rattazzi, onde nos reuníamos no início da tarde, para um velho e histórico, austero e sem reboque, café (e restaurante) da rua Pó, onde as reuniōes aconteciam no começo da noite, e alguns de nós, mais emancipado ou menos doméstico que eu, consumia o almoço a preço fixo.

Tommaso Fiore e o seu Virgilio foram o assunto de um destes encontros: Monti tinha escrito ou estava escrevendo, se lembro bem, uma resenha sobre o livro (mas năo consegui encontrar traços dela). E Virgilio era um dos seus temas de reflexăo e de estudo ao qual, acredito, teria desejado voltar com maior vigor, talvez, se a veia

Este texto foi publicado em Rassegna Pugliese, Anno II, nn. 4-7, abril-julho, 1967, pp. 246-251, Edizioni del Centro Librario, Bari-Santo Spirito. E republicado em La Gazzetta del Mezzogiorno, A. 89, n. 151, 04/jun/1976, p. 3. Agradecemos ao Instituto Norberto Bobbio pela gentileza da cessâo dos direitos de traduçâo e publicaçâao deste texto. Traduçăo de Erica Salatini. Revisāo técnica de Rafael Salatini 
do narrador, por tanto tempo reprimida, liberada justamente naqueles anos, năo o tivesse feito se tornar, com quase cinquenta anos, escritor de romances. Deste interesse virgiliano, fica como testemunho o artigo que Monti escreveu para "La Cultura" de De Lollis, em 1933, a propósito do Virgilio Minore [Virgilio Menor], de Augusto Rostagni, no qual é dedicada ao Virgilio de Fiore, "livro capital nesta matéria", a última página com calorosa e convencida admiraçâo: "Problema histórico, se existe um. Agora queremos dizer que Tommaso Fiore, estudando a poesia de Virgilio, năo tenha se colocado este problema, náo o tenha meditado, náo o tenha resolvido tanto quanto qualquer outro? Tommaso Fiore fez tudo isso..." (p.765).

Na minha lembrança, o Virgilio de Fiore se coloca ao lado do Horácio de Giustino Fortunato, do qual Monti tinha falado em primeiro lugar em "Il Baretti", em 1926 e sobre o qual teria voltado com um ensaio mais amplo na coletânea de estudos em memória do grande meridionalista ("aquele revelador da questâo meridional", I miei conti con la scuola [As minhas contas com a escola], p. 17): Il cultore di Orazio [O cultor de Horácio], in Giustino Fortunato, ediçăo do Arquivo histórico para a Calábria e a Lucania, 1939. Este volume, que se tornou hoje, creio, bastante raro, que eu tinha adquirido por conselho (conselho-comando) de Leone Ginzburg, constituiu para mim, político nâo precoce, aliás, relutante, a iniciaçấo à questâo meridional. Em uma página do seu ensaio, Monti, entre outras coisas, relatava um trecho de uma carta, a ele endereçada, de Fortunato, em que se liam estas palavras: "Sim senhor, conheço, estimo e amo Tommaso Fiore, rara avis da terra de Horácio... Sim senhor, conheço-o e o estimo muito bem" (p. 189). Mas, repito, o que sobrevive na minha memória do Fiore de Monti, é mais o estudioso de Virgilio, o humanista, aquele que tinha indicado o caminho certo, entre a árida filologia e a vácua estética, para ler e entender Virgilio, isto é, para ler e entender historicamente Virgilio. Lendo I miei conti con la scuola [As minhas contas com a escola], teria aprendido, muitos anos mais tarde, que o livro de Fiore estava entre as obras que o "profe" aconselhava aos seus escolares, junto de Vita di Dante [Vida de Dante] de Umberto Cosmo e Storia d'Italia [História da Itália] de Benedetto Croce. Sobreviveu mais o estudioso que o meridionalista, o assíduo colaborador, desde 1923, de "Rivoluzione liberale" [Revoluçấo liberal], do qual Gobetti tinha publicado, um após o outro, em 1924, dois livrinhos de memória e de reflexôes de guerra (Eroe svegliato, asceta perfetto [Herói acordado, asceta perfeito] e Uccidi [Mata]).

Monti tinha muitas razóes em nos falar de Fiore, de considerá-lo e de nos apresentá-lo como um irmăo espiritual: antes de mais nada, a experiência comum de combatentes, primeiro ardentes e depois desiludidos, portanto, a participaçâo comum na luta antifascista no caldeirăo cultural gobettiano. Fiore era o que, na tensâo do conflito de Gobetti com o deputado Delcroix e com os seus insolentes defensores havia escrito: "Matteotti também era culpado de lesa pátria. Porque entăo năo suprimir Gobetti? Tudo está para começar... Entăo viva Dumini!" ("La rivoluzione liberale" [A revoluçāo liberal], de 23 de setembro de 1924, agora no volume Incendio al Municipio [Incêndio no Município], Manduria, Lacaita Editor, 1967, pp.69-71); o número foi retirado de circulaçăo pela polícia. Enquanto escrevo, observo algumas cartas inéditas de Fiore a Gobetti, escritas entre 1923 e 1925. Na última de 3 de dezembro, escrita poucos dias antes que Gobetti partisse para o exílio, portanto, carta de adeus, lê-se: “... e aqui (Fiore escrevia de Altamura) a decadência é simplesmente fantástica. Os quadros do fascismo começam a abraçar os Italianos vivos, mortos e os que văo nascer. Mas o importante é que ao menos aqueles dez 
que restam tenham uma palavra de ordem única, para se reencontrar, materialmente e espiritualmente". Monti e Fiore estavam entre "aqueles dez" que restaram. Por parte de Monti, havia, além disso, a paixăo, de piemontês redimido por atávicos preconceitos em relaçấo às pessoas do Sul, ao lado do amigo e companheiro Giuseppe Isnardi, pela questăo meridional, considerada uma questăo nacional. Mas todas estas razóes eram sustentadas e vivificadas pelo modo comum de entender a escola, a escola deles, que era a escola do latim e do grego, e o ofício de ensinar desta escola que deveria ser, antes de tudo, escola de humanismo: ou seja, de ser humanistas modernos, no sentido que Monti havia ilustrado no livro, também gobettiano, Scuola classica e vita moderna [Escola clássica e vida moderna]. Talvez por isto, náo obstante os laços, náo apenas literários, mas ainda políticos de Fiore com Turim, a sua imagem que permaneceu impressa entấo na minha memória, a sua imagem ideal, como a chamei, foi, sobretudo, a de autor da poesia de Virgilio.

O conhecimento real nasceu dos encontros em Turim, após a última guerra, intercalados por uma visita a Bari que ele fez por ocasiăo de uma conferência minha em 1961. No meio tempo, o personagem Monti foi se enriquecendo aos meus olhos de outro traço muito humano por meio das histórias de confinamento de Maria Ginzburg, irmá de Leone, que tinha feito amizade com Fiore, ele também confinado em um pequeno vilarejo dos Abruzzi, nos primeiros anos da guerra. Leone havia conhecido Fiore, muitos anos antes, em Nápoles, na casa dos Croce, quase por acaso, para onde Leone tinha se dirigido, no final de 1932, após ter superado, em Roma, o exame de livre-docência em literatura russa. Depois Fiore foi a Turim para encontrar Leone, recém casado, nos anos em que eu estava girando pela Itália no meu noviciado universitário. Nas lembranças de Maria, Fiore aparecia sempre no gesto de homem generoso e gentil, simples e confiável, que se dedica às necessidades dos pobres, fala a linguagem dos humildes sem humilhá-los, e consegue se fazer entender porque diz coisas honestas, claras, diretas, que colhem o essencial; e mesmo quando volta 0 discurso para coisas doutas, náo veste nunca o hábito curial. Foi um acaso realmente singular que Fiore tenha entrado no ciclo da minha vida por meio de dois mestres tăo competentes, moralmente competentes, como Monti e Leone. Tanto é verdade que, pensando bem, o conhecimento real, foi um mero acidente. Năo digo que năo tenha servido para dar corpo à imagem ideal; mas aconteceu quando aconteceu, e nâo importa quando, sem surpresas, como um fato que poderia também năo ter acontecido, mas uma vez acontecido, inseriu-se tăo bem em uma história ideal já toda predisposta, mas ainda náo totalmente explicada, a ponto de perder todo relevo particular.

Enquanto isso, o estudioso de Virgilio, que tínhamos aprendido a conhecer por meio de Monti, voltado para o estudo do humanismo renascentista, havia traduzido Erasmo para a editora Einaudi; traduzido e introduzido a Utopia [Utopia] de More para a editora Laterza, nos mesmos anos (por volta de 1940) em que eu mesmo, tomando uma estrada que teria abandonado depois (aqui também havia tido a inspiraçăo de Leone), tinha me ocupado com dedicaçăo (mas sem um verdadeiro entusiasmo intelectual) de a Città del Sole [Cidade do Sol] de Campanella (outro Tommaso). Na história da fortuna da utopia política durante o fascismo, o meu nome deverá ser colocado ao lado do de Fiore, mesmo que a intençăo que tenha nos movido tenha sido diversa: a minha, histórica-filológica, a de Fiore, quem sabe, também política. Năo posso deixar de recordar um dos trechos mais belos de um dos seus caderninhos de 
guerra, quando o filósofo diz aos seus companheiros de taberna, incrédulos, que a guerra tinha por objetivo conquistar o reino de Utopia. Mas entăo onde era este reino? Os geógrafos tinham se esquecido de assinalá-lo nos seus mapas e os ministros năo tinham colocado esta conquista entre os objetivos de guerra. O filósofo responde: "Mesmo se năo se conquista a regiăo de Utopia, a guerra é inútil". Ao invés do reino da Utopia teria vindo a sórdida realidade do fascismo. Ocupar-se da obra de More queria dizer que o advento do reino da Utopia estava apenas adiado?

Mas Fiore nâo era um utópico. Entâo perdi uma aula, bem mais profunda e concreta, que teria podido aprender do estudioso de More. Muitos anos antes, no "Humanitas", jornal, aliás, "gazeta autárquica" de Bari, no número de 4 de fevereiro de 1923, Fiore havia escrito um artigo sobre Carlo Cattaneo (agora reproduzido no volume já recordado Incendio al Municipio [Incêndio no Município], pp. 29-37), onde entre outras coisas se lia: "Sempre olhei com admiraçăo e estupor o prodígio Cattaneo... É necessário dizer que o homem é muito elevado para nós, que năo conseguimos tornar a sua profundidade nossa, o seu senso de liberdade, a sua olímpica segurança no domínio dos fatos históricos". Quando comecei a me ocupar de Cattaneo, entre 1943 e 1945, este artigo, mesmo mencionado na assídua biografia de Alessandro Levi, tinha permanecido inacessível para mim. (Apenas pouco tempo atrás, uma coletânea, acredito, muito rara, do jornal "Humanitas", começou a fazer parte da biblioteca do Centro de Estudos Piero Gobetti). A inspiraçáo e o impulso de me aproximar de Cattaneo nâo foram desiguais, mesmo que a matriz cultural da qual tinha nascido o cattaneismo de Fiore fosse diferente. $\mathrm{O}$ meu mediador foi com certeza Einaudi; o mediador de Fiore, provavelmente, Salvemini, que foi o primeiro a inserir o pensamento do reformador lombardo na cultura meridional. Mas, em suma, gosto de pensar que o amor comum por Cattaneo seja, agora, um laço muito mais estreito que o interesse momentâneo pela utopia renascentista.

Conheci Fiore, como dizia, por meio de suas conferências em Turim após a liberaçăo: lembro-me daquela feita por ocasiăo do lançamento do seu livro pela Einaudi, Il cafone all'inferno [0 camponês no inferno], na Uniâo cultural na sua primeira versăo (isto é, organizaçâo artesanal, público de amigos e condescendentes, a velha guarda compacta e a nova que tenta crescer ou procura outras formas). Apresentado por Perrini, também da Puglia, professor de história e filosofia há muito tempo em um liceu de Turim, e um amigo desde os tempos de juventude (encontro o nome de Perrini em uma carta a Gobetti de 7 de novembro de 1924), Fiore falou com naturalidade, sem retórica, mas com grande força persuasiva, como se estivesse entre velhos amigos. Uma conferência de Fiore nunca é uma demonstraçâo de doutrina, nem tanto menos um exercício oratório, no máximo um discurso didático mais pela substância que pela forma: um falar e um falar-se francamente, um convite a um colóquio. Aliás, a conferência é ela mesma um colóquio ideal, com um público que se presume năo inerte, mas compreensivo, capaz de responder às perguntas indiretas, às alusōes, de consentir e, enfim, de se tornar ele mesmo parte do jogo. A última vez que o ouvi faz dois anos: uma leitura para poucos jovens reunidos no Centro Gobetti, de uma seleçăo de poemas do poeta lucano Albino Pierro, do qual é férvido admirador, e um perito tradutor; um discurso improvisado, de velho mestre em uma escola profissionalizante, sobre os problemas da nova escola, dedicado integralmente a um público de operários. 
Falando de poesia ou política, literatura ou escola, Fiore propóe continuamente nos seus discursos sempre dois temas fundamentais. O primeiro é a nobreza do homem; de todos os homens, por isso náo devemos nunca nos cansar de buscar em cada um dos nossos iguais o fundo de humanidade e de ressaltar neles a essência profunda. Daqui a sua fé, nunca ausente, nos jovens, a sua vocaçăo pedagógica, da qual as cartas a Mario Melino, recentemente publicadas, sâo testemunhas. Nâo posso esquecer com que trepidaçăo e com que sentimento de simpatia humana falava, dois anos atrás, a estudantes em uma angustiante espera para fazer o exame de maturidade $^{2}$ diante da comissăo da qual ele era presidente em um liceu em Turim. E todos os dias oferecia, gesto de realeza, um maço de flores ao melhor. Ao lado da nobreza, o segundo tema é aquele estritamente ligado ao primeiro, do sofrimento do homem, que é algumas vezes torpeza tăo baixa que cancela todo vestígio de dignidade, mas que deve ser compreendida, e mais que compreendida, assumida como um peso a se carregar, como uma responsabilidade a atingir, como uma tarefa a executar, porque apenas deste modo pode ser redimido.

Por força de falar de humanismo, essa palavra se desvalorizou e se corrompeu tanto que nâo temos mais a coragem de usá-la. E até quando nos seja permitido usá-la -e náo encontramos outra melhor - para resumir em uma fórmula a mensagem civil de Tommaso Fiore, nâo terá perdido toda a sua força representativa. Humanismo como a concepçăo da história pela qual este mundo das naçóes, teria dito Vico, foi feito pelos homens, e visto que foi feito pelos homens - acrescentamos nós modernos, com maior consciência do nosso poder e da nossa responsabilidade -, năo apenas podemos conhecê-lo, mas devemos continuamente fazê-lo e refazê-lo à imagem e semelhança do homem ideal que a história a cada vez nos indica.

2 Exame nacional que os alunos italianos prestam para conseguir o diploma do ensino médio. (Nota da tradutora) 